\title{
Variability of the reproductive cycle in estuarine and coastal populations of the mussel Mytilus galloprovincialis Lmk. from the SE Bay of Biscay (Basque Country)
}

\author{
K. Azpeitia $₫$ - M. Ortiz-Zarragoitia $\cdot$ M. Revilla $\cdot$ \\ D. Mendiola
}

Received: 28 April 2017/ Accepted: 12 October 2017/Published online: 23 October 2017

(C) The Author(s) 2017. This article is an open access publication

\begin{abstract}
Mussel commercial production depends on wild populations to obtain the seed. Therefore, any new farming initiative needs deep knowledge on reproductive cycle of native mussel populations. The reproductive cycle of Mytilus galloprovincialis Lmk. from five sites, three estuarine and two coastal, along the coast of the Basque Country were assessed using gonad index and stereology over 2 consecutive years (2010 and 2011). Sex ratios, developmental stages of gonads, as well as reserve tissue cycle were analyzed. The onset of gametogenesis was observed from winter to spring, with spawning occurring from spring till summer. A resting phase followed with an increase in reserve tissues (adipogranular cells) was observed in fall. Mussels stayed ripe during winter until favorable environmental conditions were met in spring. Differences in reproductive cycles were found among populations, and also, year-to-year variability was observed within each population. In two of the studied sites asynchrony in the timing of spawning was observed between genders. These timing differences, however, did not prevent mussels at those sites from reproducing successfully. The Bidasoa estuary points to the potential of such studied sites for becoming the main source of wild mussel spats for future expected commercial mussel farming in the Basque Country. To ensure year-toyear maximum reproductive output, however, wild mussels harvest should be avoided from spring to the end of summer in this region.
\end{abstract}

Keywords Mytilus galloprovincialis Lmk. - Reproductive cycle · Condition index · Stereology · Bay of Biscay

\section{Introduction}

Open-ocean aquaculture represents a promising alternative for sustainable cultivation of bivalve species (Polk 1996; Hesley 1997; Stickney R 1998; Bridger and Costa-Pierce 2003), especially in regions with restricted coastal space for farming activities such as the Basque Country (Azpeitia et al. 2016). Analyzing the health of wild mussel populations in relation to their reproductive cycle and spat production is important as mussel production relies on the annual collection of significant amounts of wild seeds, and farmers grow these seeds

K. Azpeitia · M. Revilla $\cdot$ D. Mendiola $(\bowtie)$

AZTI-Marine Research, Herrera Kaia, Portualdea z/g, 20110 Pasaia, Spain

e-mail: mendiazti@gmail.com

M. Ortiz-Zarragoitia

Plentzia Marine Station (PiE), University of the Basque Country (UPV/EHU), Areatza z/g, 48620 Plentzia, Basque Country, Spain 
in extensive marine areas (Domínguez et al. 2010). For commercial activity, the industry must be provided with solid information on the opportunities and risk before promoting an investment; in this regard, basic aquaculture research is a necessary step to establish a healthy mussel industry in the region (Langan and Horton 2003). Herein, areas favorable for spat collection and/or targeting rope deployment periods for spat settlement is of particular relevance in mussel aquaculture and further, will be fundamental for developing future farming management strategies (e.g., protect native spawning stocks and/or larval settlement) (Gosling 1992; Dias et al. 2009). Moreover, prudent regulation of harvesting will maximize reproductive output of wild and cultured mussel populations.

To establish the adequacy of different sites of the Basque coast for spat collecting, we need to understand the basic reproduction of wild mussel populations inhabiting those environments. The regulation of gametogenesis and spawning in marine bivalves is considered a genetically controlled response to the environment (Sastry 1979; Barber and Blake 1991). Temperature and food availability regulate gametogenic cycle and associated storage of materials (Gabbott and Bayne 1973; Seed 1976). In fact, gametogenesis can be energetically supported from two sources: reserves stored in the mantle tissue cells (Bayne 1976; Gabbott 1976); directly ingested nutrients (Newell et al. 1982; Thompson 1984); or a combination of both (Barber and Blake 1991).

The group of Mytilus spp. is composed of gonochoristic species with low hermaphroditic prevalence (Seed 1976). Although size for sexual maturity depends on the growth rate of each individual, sexual maturity is reached in the first year of life (Bayne 1976). The reproductive system is composed of mantle tissue and consists of reproductive cells, circulatory system and connective tissue cells. The mantle tissue has two interrelated physiological functions. First, the accumulation of reserves and second the development of the gonad that invades the mantle proliferating at the expense of the reserve tissue.

Studies held in the SE Bay of Biscay described that gametogenesis in wild mussels occurs in winter months and the active reproductive period in spring. In warm and nutrient rich years, a second reproductive peak can be seen between summer and fall (Ortiz-Zarragoitia and Cajaraville 2010; Garmendia et al. 2010; OrtizZarragoitia et al. 2011; Cuevas et al. 2015).

The aim of the present study was to determine the dynamics of the reproductive cycle along with the patterns of energy storage and utilization, in five Mytilus galloprovincialis populations from the Basque Country (SE Bay of Biscay). In a previous study, shellfish aquaculture had been experimentally tested in the open waters of the SE Bay of Biscay (Azpeitia et al. 2016). The present study focuses on reproductive cycle and nutrient storage, and it is considered necessary to assess both sustainable exploitation rates for this species and potential capacity for aquaculture production in the region.

\section{Materials and methods}

Study area

The Basque coast is located in the SE Bay of Biscay. Basque region coast extends over $150 \mathrm{~km}$ approximately, and it is oriented E-W. There are 12 main estuaries along this coast. This study was conducted at five sites: two exposed coastal sites (Nerbioi coast and Mutriku coast), and three sheltered estuarine sites (Nerbioi, Oiartzun, and Bidasoa estuaries) (Fig. 1).

The two exposed coastal sites included in this study are euhaline. The rivers Nerbioi and Bidasoa have the highest flows along the Basque coast (26-36 $\mathrm{m}^{3} \mathrm{~s}^{-1}$, annual mean), whereas the river Oiartzun has a much lower annual flow $\left(4.8 \mathrm{~m}^{3} \mathrm{~s}^{-1}\right)$. The Basque estuaries have semi-diurnal tides, with tidal amplitudes that can vary between $1 \mathrm{~m}$ in neap tides, to more than $4.5 \mathrm{~m}$ in spring tides (Valencia et al. 2004). As such, although they present some characteristics of macrotidal estuaries, they can be considered as generally mesotidal estuaries (Hayes 1975).

These locations have been selected as they represent different water systems (exposed and sheltered sites, with different water flows and different environmental characteristics. In addition, they contain relatively large wild-mussel populations along the Basque coast. Further, environmental data from these sites were available. 


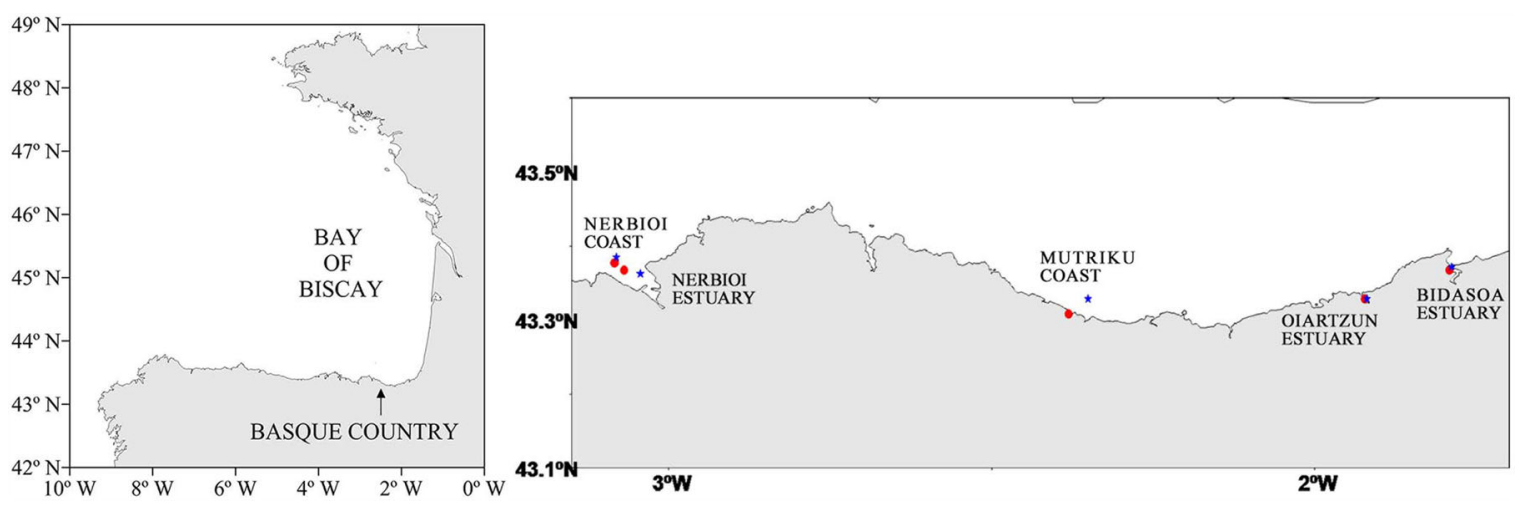

Fig. 1 Geographical location of the sampling stations used for the biological (red spots) and environmental variables analysis (blue spots): Nerbioi coast, Nerbioi estuary, Mutriku coast, Oiartzun estuary and Bidasoa estuary

Environmental data

To characterize the environmental conditions that could influence reproduction in mussels, data on physical and chemical variables, together with chlorophyll- $a$ concentration (as a proxy for phytoplankton biomass) were used.

In the Basque Country, the marine environment has been monitored since 1994 by means of the Littoral Water Quality Monitoring and Control Network (LQM) (Borja et al. 2004, 2009). Environmental data are acquired on a quarterly basis (usually in February, May, August and November), in nearshore open waters as well as in estuaries. The present study draws on data from the LQM sites that are located nearest to the biological stations (Fig. 1).

Environmental variables were measured in surface waters and consisted of salinity, temperature, chlorophyll- $a$ (Chl- $a$ ), total nitrogen (TN), total phosphorus (TP), total organic carbon (TOC) as well as, suspended solids (SS). Salinity, temperature and Chl- $a$ (estimated from fluorescence) were measured "in situ" by means of a CTD (Sea-Bird). Laboratory methods for TN, TP, TOC, and SS can be consulted in detail in Garmendia et al. (2011).

Sampling strategy for mussels

Mussel sampling was done bimonthly over two separate periods of 11 months each. The first, from April 2010 to February 2011 and the second, from April 2011 to February 2012. Samples were taken in each season to characterize intra-annual variability: spring (April), summer (June and August), fall (October), and winter (February). No samplings were conducted in December. However, as the summer season is of key importance for reproductive cycle and spat collection, 2 months were sampled in both years (years 2010 and 2011), one at the beginning and one at the end of the season.

On each occasion, 20 subtidal mussels per site were randomly collected by hand, by scuba divers, during low tide at $1 \mathrm{~m}$ depth. Specimens were $3.5-6 \mathrm{~cm}$ long, thus sexually mature mussels (Izagirre et al. 2014). Mussels used for histological analysis were directly fixed in the field, by sectioning the adductor muscle and introducing it in neutral buffered formalin for at least $24 \mathrm{~h}$.

Sex ratio, gamete development, and gonad index

The gonad (mantle tissue) from each mussel was dissected out after fixation, placed in histological cassettes in $70^{\circ}$ ethanol and routinely processed for paraffin embedding in a Leica ASP300 automatic tissue processor (Nusloch, Germany). Sections of 3-5 $\mu \mathrm{m}$ thick were cut in a Leitz 1512 microtome (Vienna, Austria) and stained with hematoxylin and eosin. The slides were examined using an Olympus BX60 microscope equipped with a digital camera. 

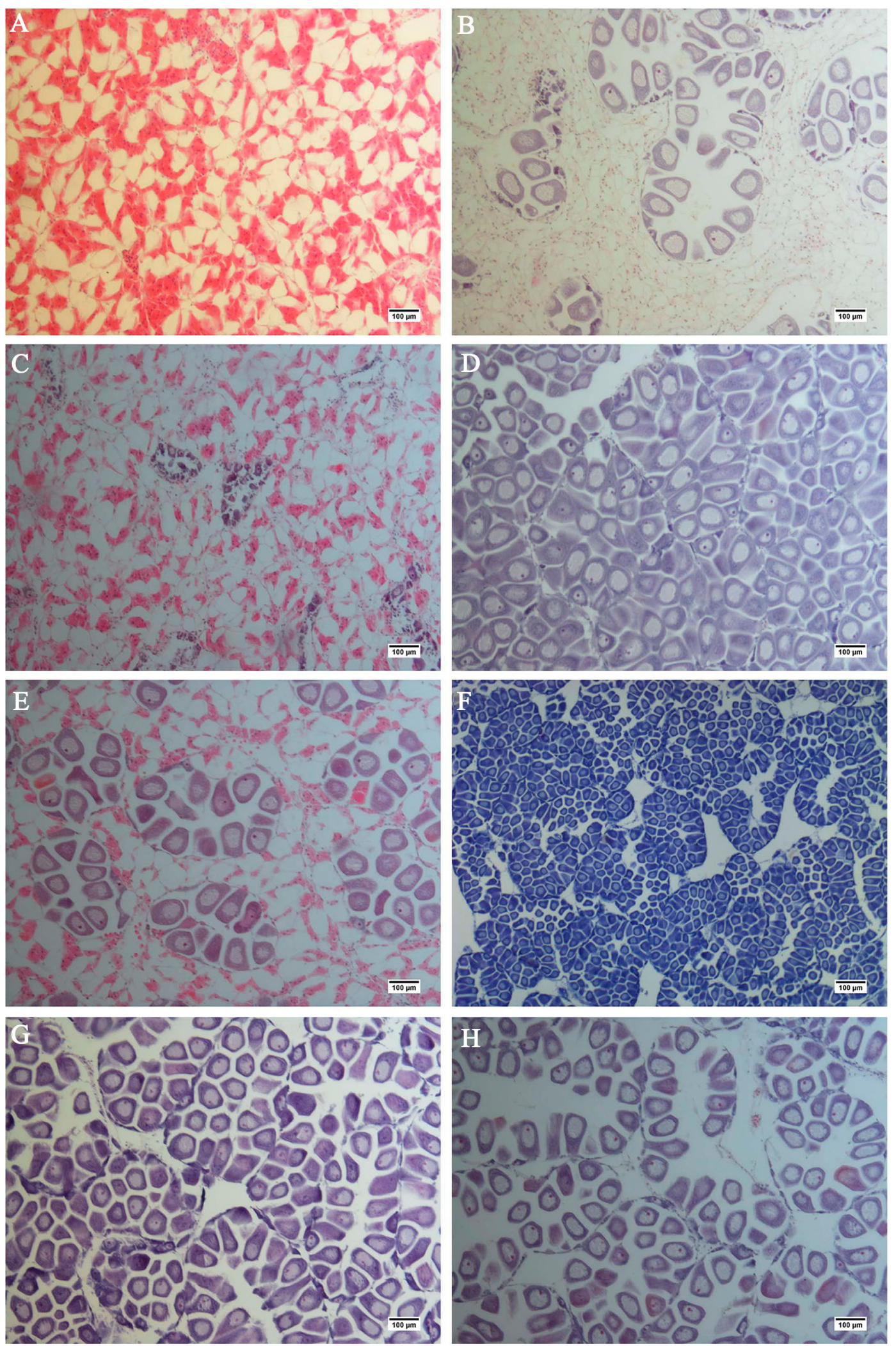
4 Fig. 2 Photomicrograph of female gonads from study sites. Gonad development stages in Mytilid and Dreissenid, nomenclature adapted from Seed $(1975,1976)$ by Hillman (1993). (1) Resting/spent gonad: stage 0 (A); (2) developing gonad: stage 1 (B, C); stage $2(\mathbf{D})$; stage $3(\mathbf{E})$; stage $4(\mathbf{F})$; (3) ripe gonad: stage $5(\mathbf{G})$; (4) spawning gonad: stage $4(\mathbf{H})$; stage 3 (I); stage $2(\mathbf{J})$; atresic gametes (K); apoptotic gametes (L); hermaphroditic gonad section from Oiartzun estuary (Spring 2010) (M) and (Winter 2011) $(\mathbf{N})$, respectively. Separate male and female follicles are observed

The sex ratio was calculated as the number of female mussels divided by number of male mussels. Afterwards, the gametogenic staging established by Hillman (1984) was applied and a gonad index (GI) value was assigned to each development stage adapted from the description of Kim et al. (2006): 1, resting (stage 0); 1.5, early gametogenic stage (stages I and II); 3.5, advanced gametogenic stage (stages III and IV); 5 mature stage (stage V); 3.5, spawning stage (stages IV, III, II and I); 1.5, post-spawning stage (stage 0) (Figs. 2, 3). A mean population GI value for each site and sampling time was then calculated from the sum of the individual stage numbers (Ellis et al. 1998), as follows:
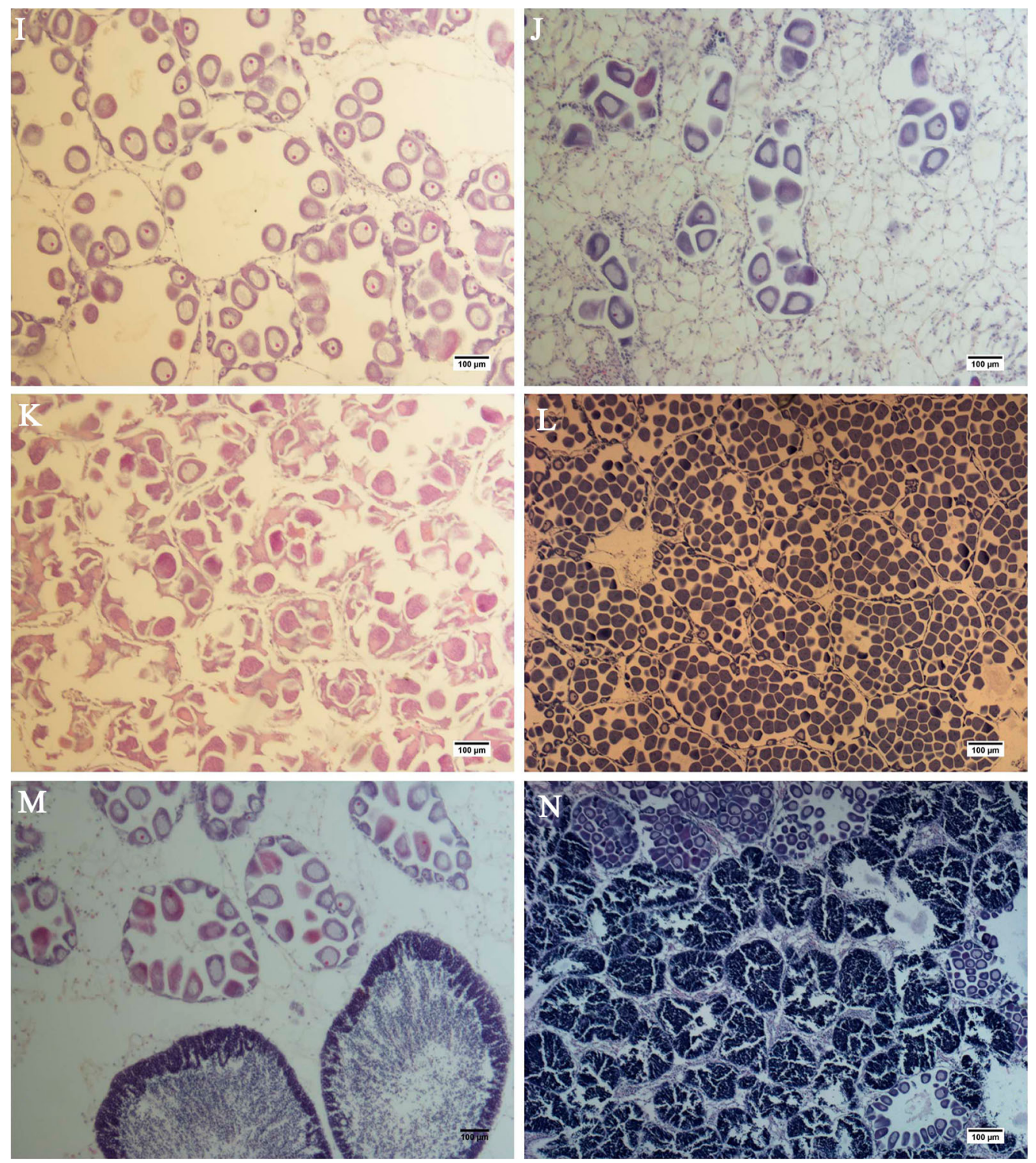

Fig. 2 continued 

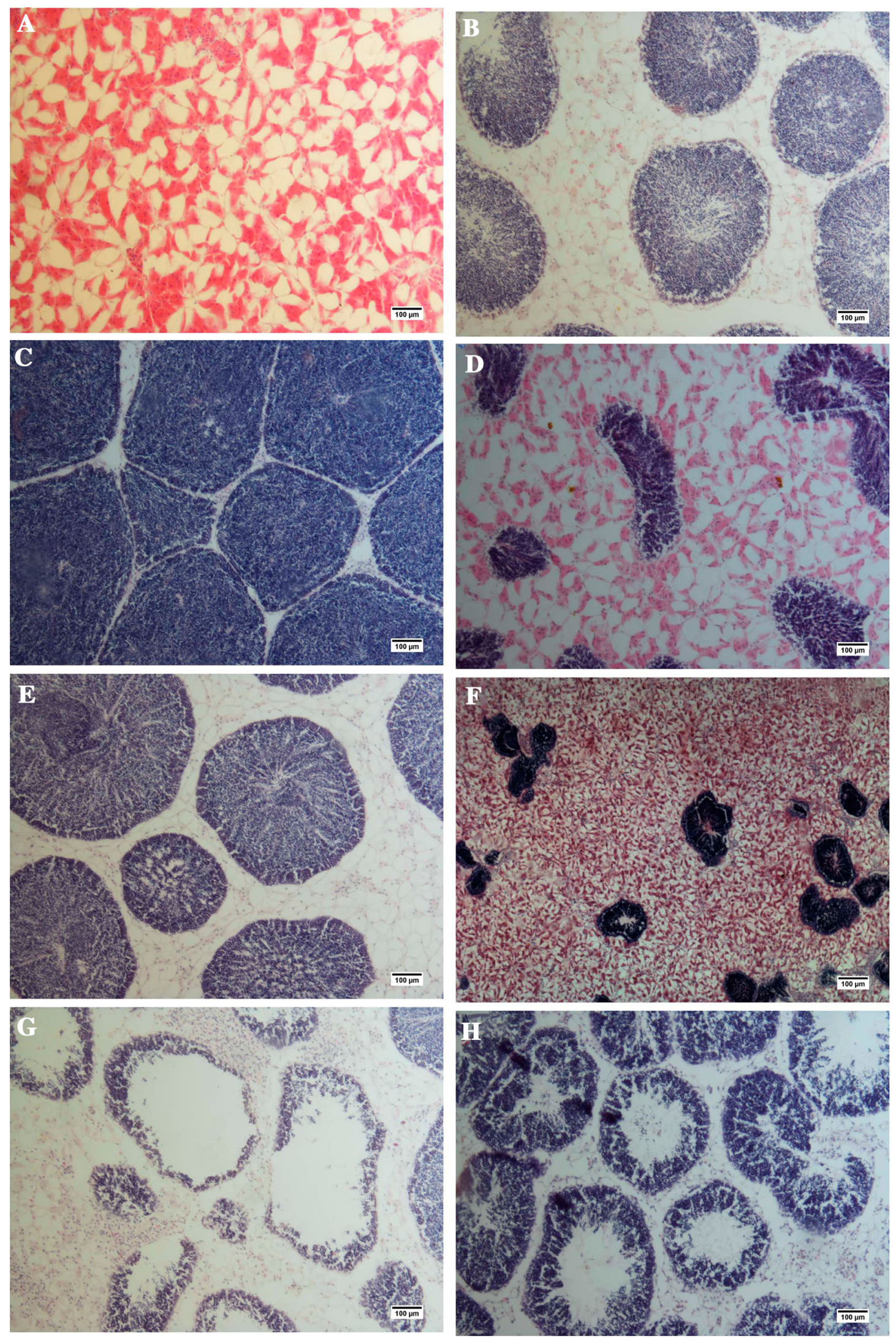
4Fig. 3 Photomicrograph of male gonads from study sites. Gonad development stages in Mytilid and Dreissenid, nomenclature adapted from Seed $(1975,1976)$ by Hillman (1993). (1) Resting/spent gonad: stage 0 (A); (2) developing gonad: stage 1 (B); stage 2 (C); stage 3 (D); stage 4 (E); (3) ripe gonad: stage $5(\mathbf{F})$; (4) spawning gonad: stage $4(\mathbf{G}, \mathbf{H})$; stage $3(\mathbf{I})$; stage $2(\mathbf{J})$; spent gonad (stage 0) (K); hemocitic infiltration $(\mathbf{L})$; parasite $(\mathbf{M})$; granulocytoma $(\mathbf{N})$

$$
\mathrm{GI}=\frac{\sum \mathrm{ni} \cdot \mathrm{Si}}{N}
$$

where ni: number of individuals at each gametogenic stage of the reproductive cycle, Si: value corresponding the stage and $N$ : total number of individuals. The index varies from zero, if the entire population is spent or resting, to five when fully ripped (sexually mature).
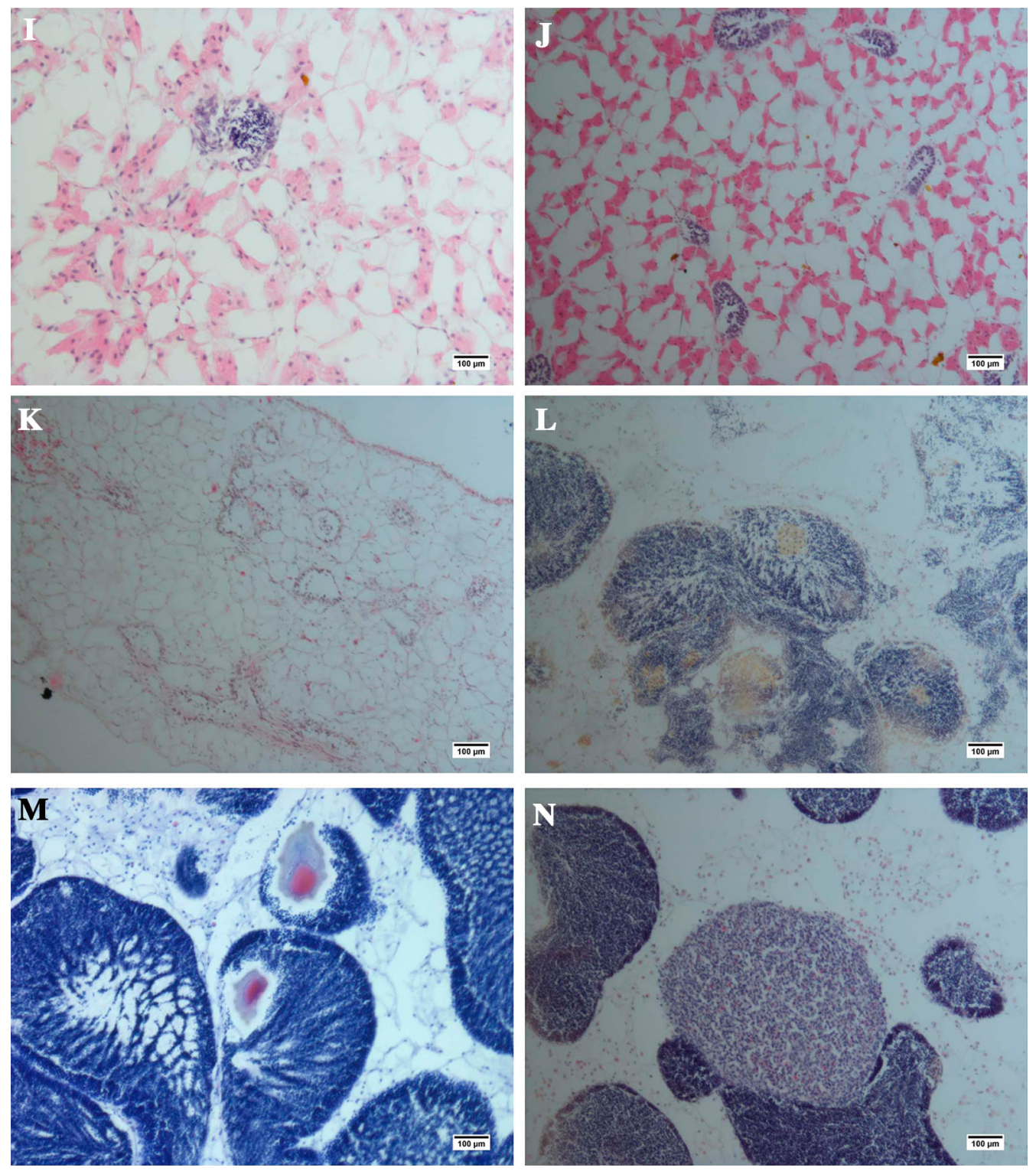

Fig. 3 continued 

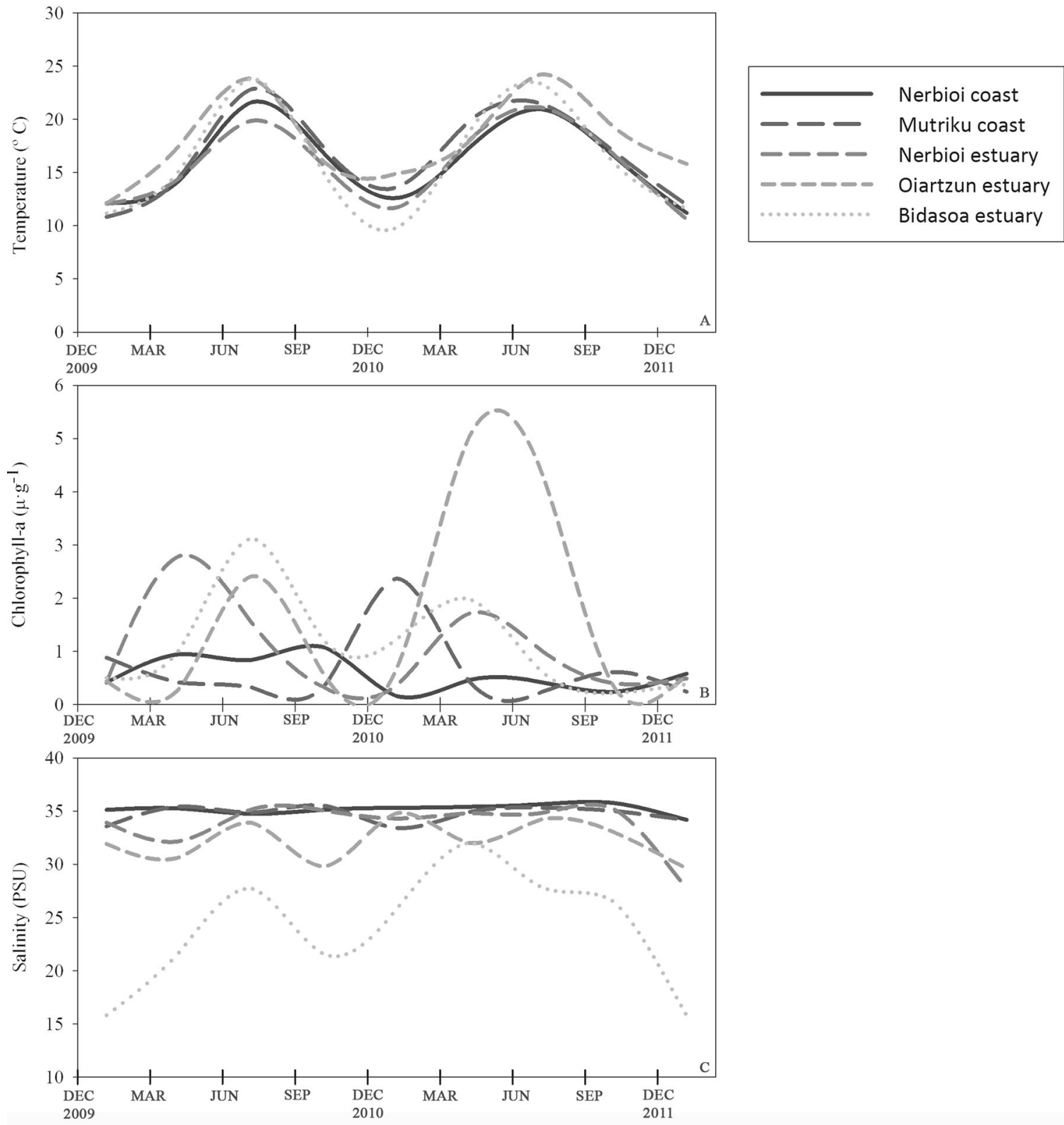

Fig. 4 Water temperature (A), Chlorophyll- $a(\mathbf{B})$ and salinity $(\mathbf{C})$ measured every 3 months during both of the studied periods

\section{Stereology}

Gonad sections of 3-5 $\mu \mathrm{m}$ were examined with cellSens (Olympus) device with a microscope at a magnification of $\times 240$ attached to it. Point counts (Weibel and Elias 1967) were made on four independent fields of the same histological section, to quantify the volume fraction of the different tissue components: adipogranular cells (ADG cells), vesicle connective tissue cells (VCT cells), developing and morphologically ripe gametes, areas of empty follicles resulting from spawning activity, haemocytes as well as, areas of pathologies (Pipe 1987). Stereological analysis was carried out using the techniques described by Lowe et al. (1982) and Pipe (1987).

An ImageJ (Rasband 2009) routine was developed to overlay digital images of histological sections with a Weibel grid (Weibel et al. 1966). The Weibel grid contained 168 points and covered an area of $0.0034 \mathrm{~cm}^{2}$. The distance between points $(35 \mu \mathrm{m})$ was smaller than the average of the smallest cell type. The volume 

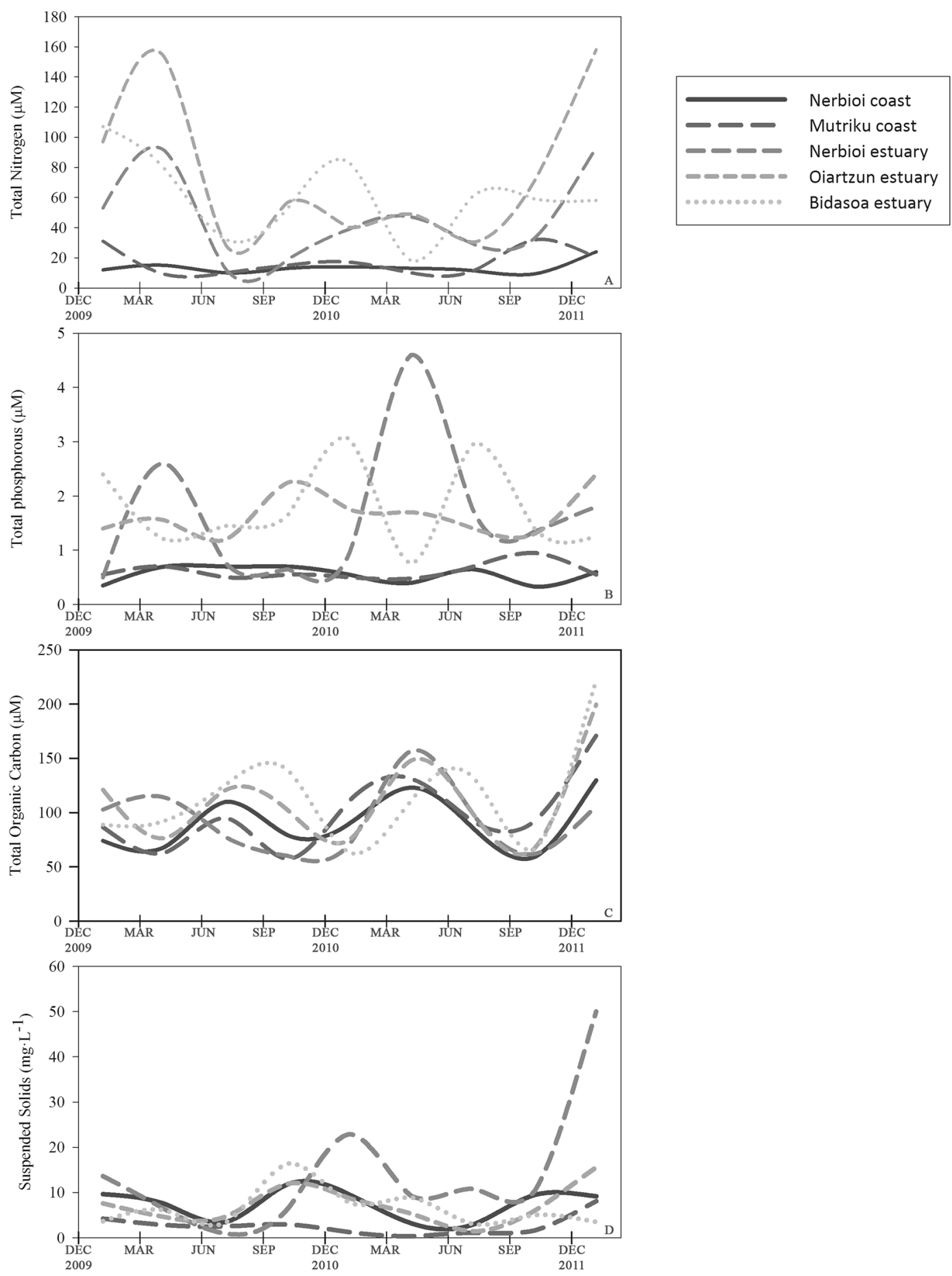

Fig. 5 Total nitrogen (A), total phosphorus (B), total organic carbon concentration $(\mathbf{C})$ and suspended solids $(\mathbf{D})$ measured every 3 months during both of the studied periods

fraction was assessed according to the mean quantity (\%) of gonad tissue occupied by the gonad tissue cellular component encountered in the four independent fields. For each analyzed site and sampling time, a mean (\%) volume fraction of each cellular component was then calculated with the data of five individuals per gender. The results were expressed as percentage of cellular component encountered in the mussel mantle per gender, site and sampling time. 


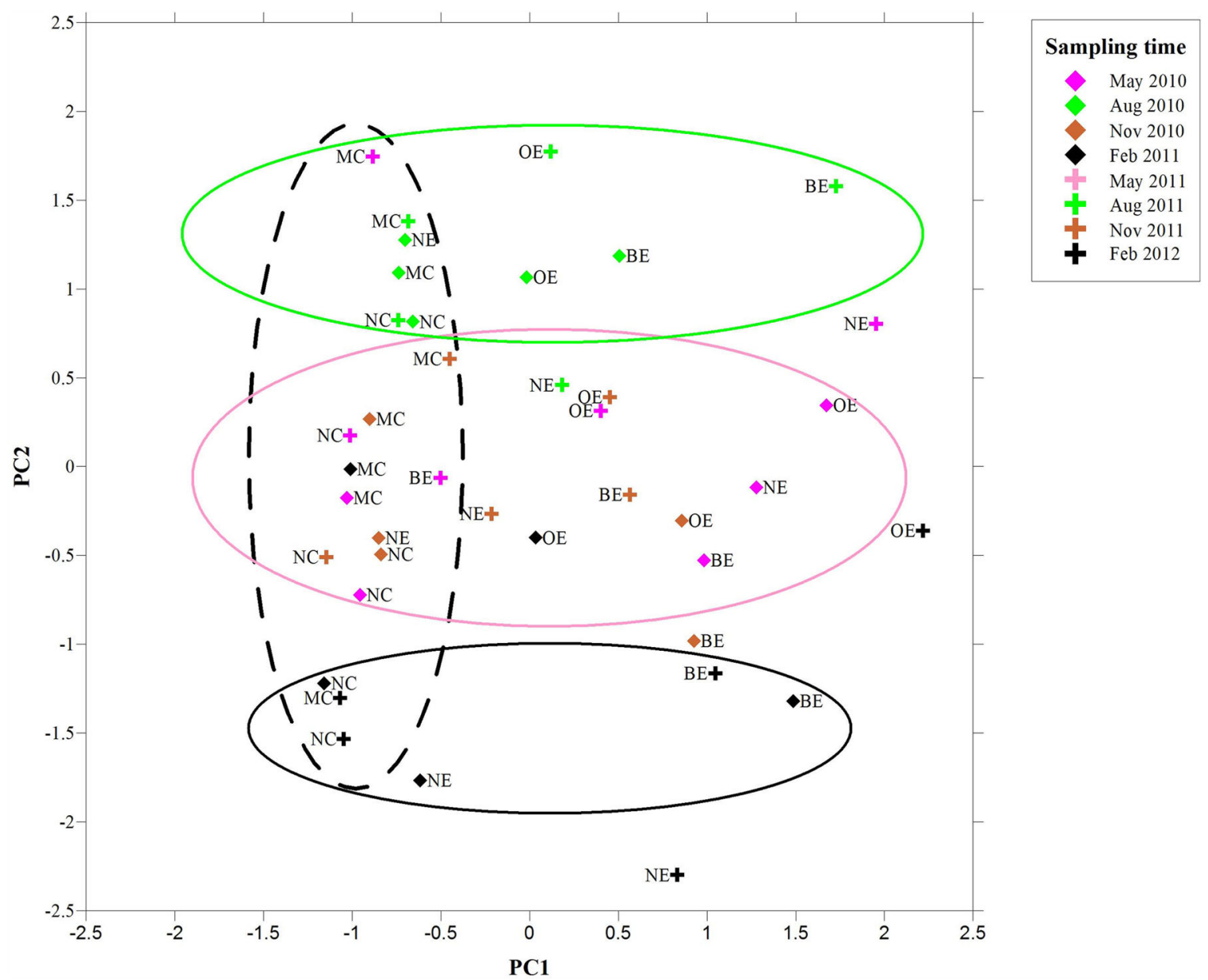

Fig. 6 Principal component analysis (PCA) of environmental data at each sampling time from the studied sites over 2 year periods. First component (PC1) associated Total phosphorous, total nitrogen and salinity and served to separate coastal sites (discontinuous vertical black circle) from estuarine sites. Second component (PC2) showed a association between temperature, suspended solids and salinity and served to separate sampled seasons: summer (continuous horizontal green circle); spring and fall (continuous horizontal pink circle); and winter (continuous horizontal black circle)

\section{Statistics}

Data were plotted using Sigmaplot (11.0) statistical and graphical software (Systat software), and statistical analysis was carried out using a statistical package (SPSS 17.0 for Windows ${ }^{\circledR}$ ). When checking for significant differences in sex ratios, gametogenic index (GI) and partial volumes of gonad tissue cellular components, only males and females were taken into consideration, undifferentiated and hermaphrodites individuals being excluded from the analysis. Data were tested for normality (Shapiro-Wilk test) and variance homogeneity (Leven's test). Spatial and temporal differences were statistically analyzed by two-way ANOVA and Tukey's test as post hoc test when homogenous variances were found, and by Kruskal-Wallis together with MannWhitney $U$ test in case of heterogeneous variances. Wilcoxon Signed Ranks test was used to test differences between genders at each studied site. Sex ratio bias was studied using Chi square Goodness-of-fit test (1 variable) comparing total number of female and male mussels and normalizing for theoretical gender bias (1:1). Significant difference was established for all cases at $p<0.05$.

Finally, principal component analyses (PCA) were run to reveal the association between environmental variables and to determine the main factors influencing variability. 

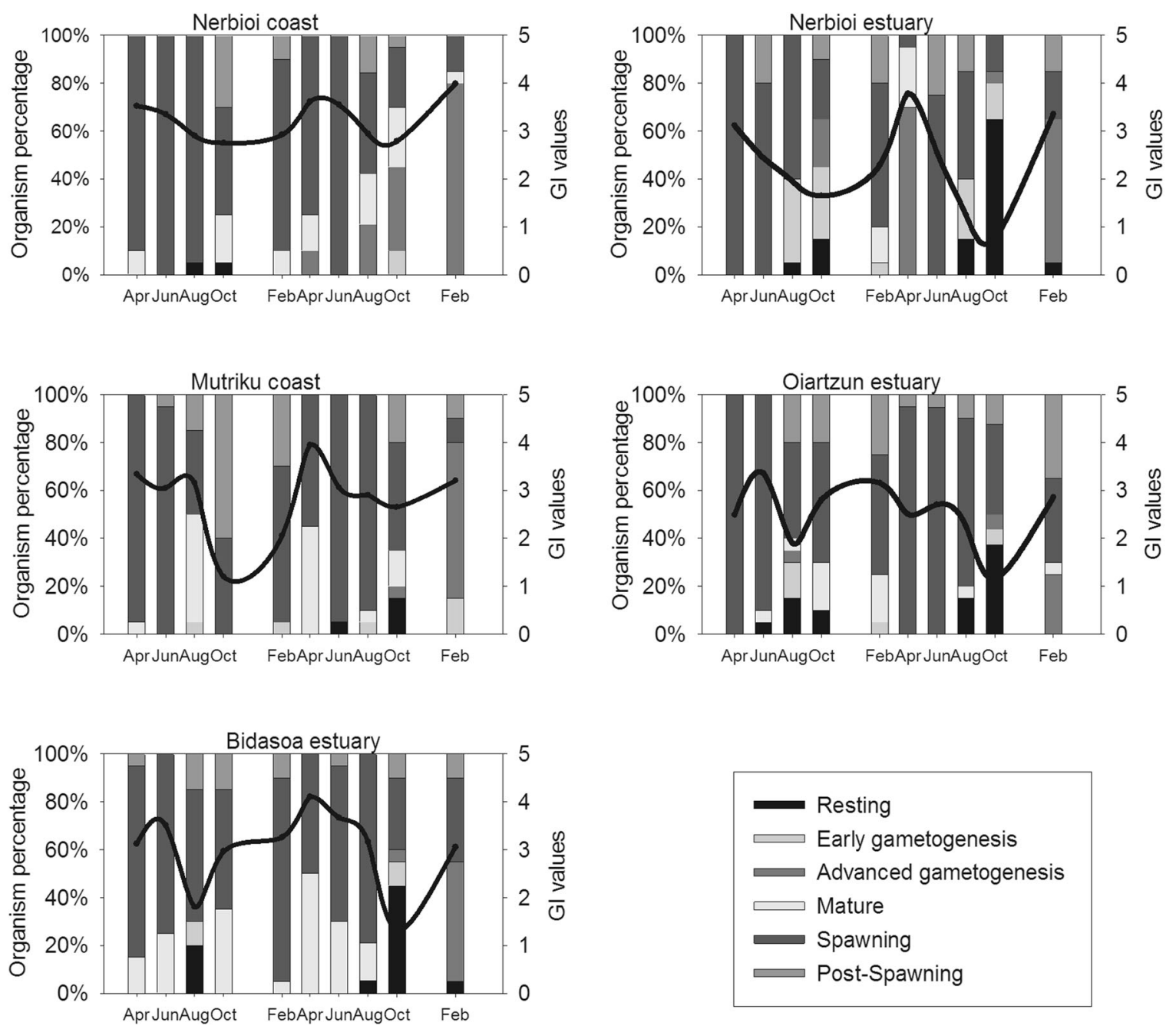

Fig. 7 The percentage distribution of gamete development phases: resting stage, early gametogenesis, advanced gametogenesis, maturity, spawning and post-spawning stage (stacked bars) and gonad index (GI) values (black solid line) of mussel populations (Nerbioi coast, Nerbioi estuary, Mutriku coast, Oiartzun estuary and Bidasoa estuary) at each sampling time over 2 year periods

\section{Results}

Environmental parameters

No statistically significant differences were found in annual temperature cycles among sites (Two-way ANOVA; $p=0.756$ ), nor between years (Two-way ANOVA; $p=0.064$ ), starting in spring 2010 and ending in winter 2012. The variability in the water temperature along the Basque coast was mainly driven by the typical seasonal cycle (Two-way ANOVA; $p<0.001$ ), and this seasonal cycle did not change between the 2 years (Two-way ANOVA; $p=0.504$ ) (Fig. 4A).

Regarding phytoplankton biomass temporal variability (Fig. 4B) along the Basque coast, statistically significant differences in the Chl- $a$ concentrations were not detected, neither among seasons (Two-way ANOVA; $p=0.111$ ), nor between analyzed years (Two-way ANOVA; $p=0.807$ ). No interaction was observed between studied seasons at each analyzed year (Two-way ANOVA; $p=0.517$ ). As for spatial variability, no significant annual differences were observed among sites, in either of the two studied years (Kruskal-Wallis test; $p=0.434$ and $p=0.451$, respectively). However, Chl- $a$ presented higher temporal variability in estuaries, compared to the open coastal sites ( $\mathrm{SD}=1.275$ vs. $\mathrm{SD}=0.5$, respectively). Salinity presented spatial variability in both years (Kruskal-Wallis test; $p=0.012$ and $p=0.012$, respectively), 

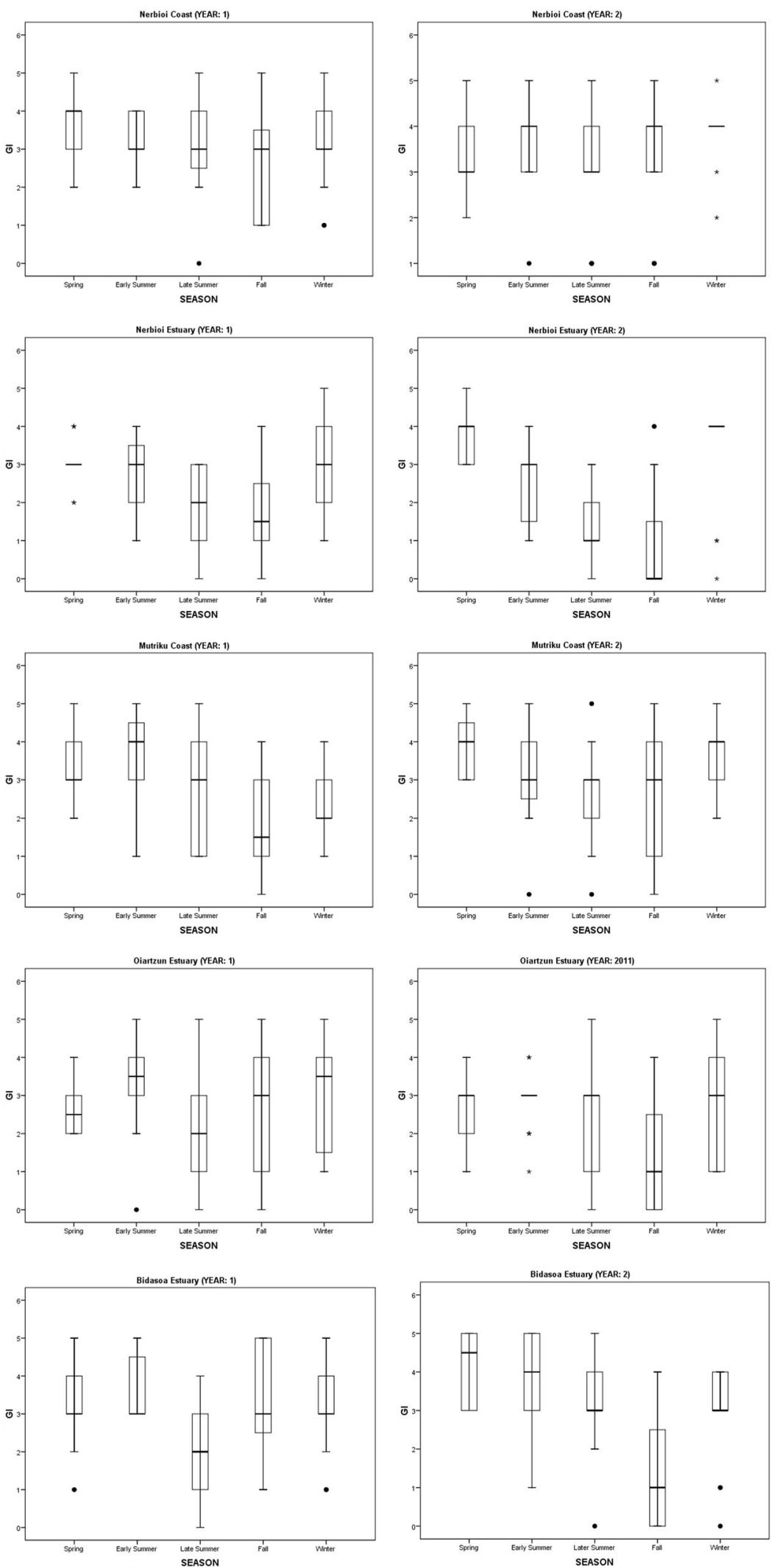

Fig. 8 Box plots showing seasonal differentiation of gonad index at each sampling time from the studied sites over 2 year periods 

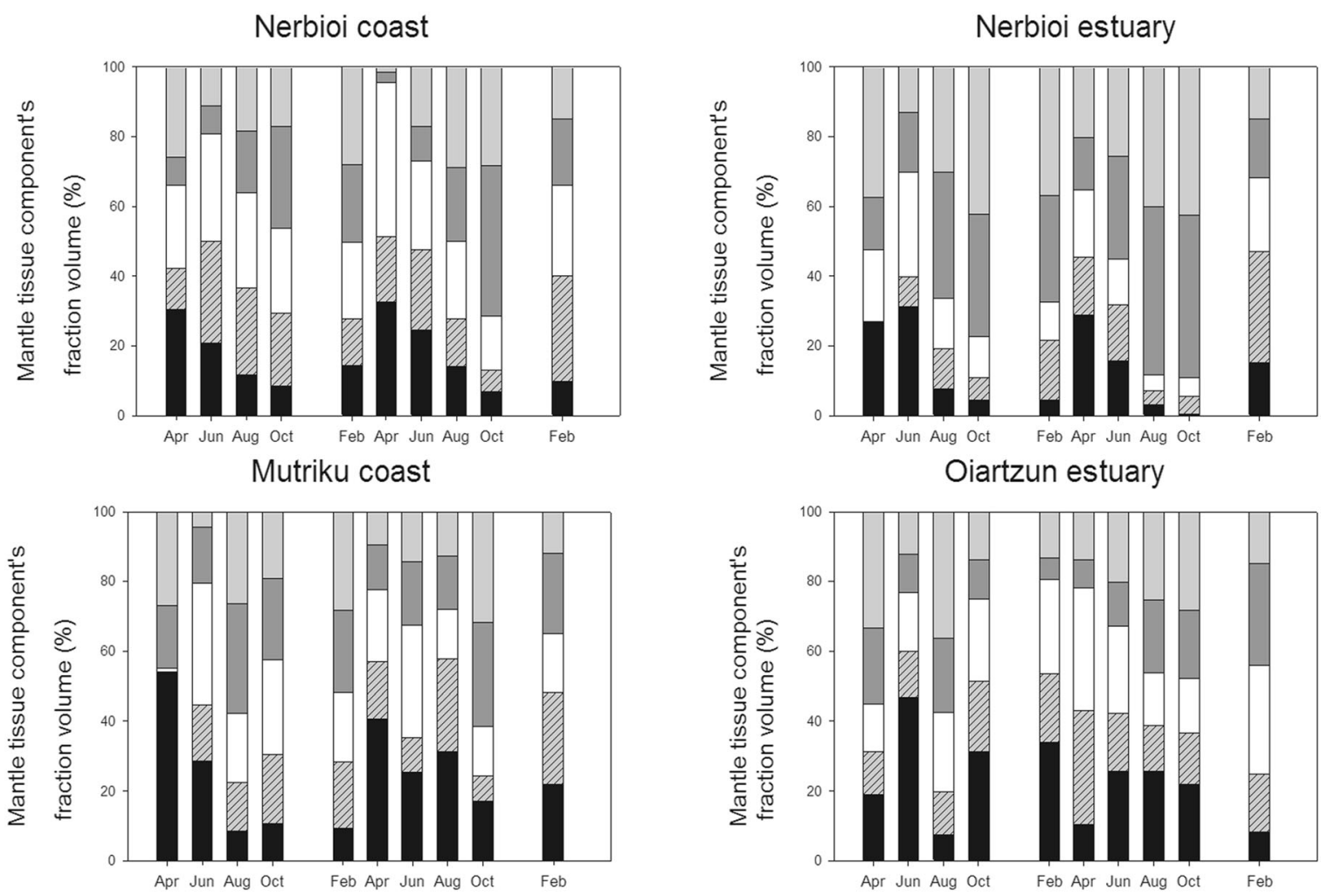

Bidasoa estuary
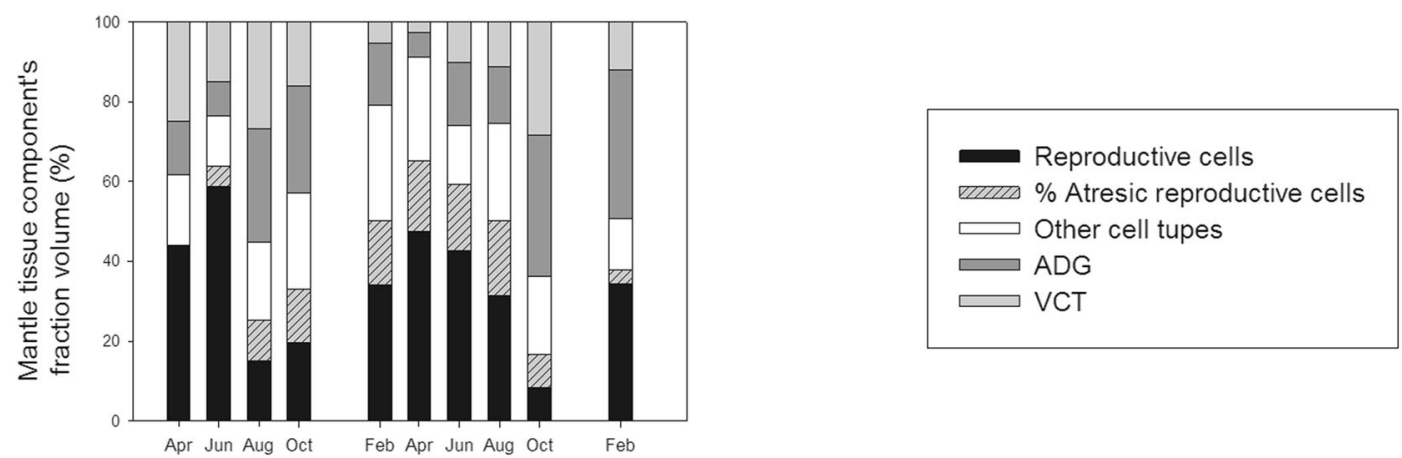

Fig. 9 Variation on female mussel mantle tissue components volume fraction (stacked bars) in the five studied sites. From top left to right: Nerbioi coast, Nerbioi estuary, Mutriku coast, Oiartzun estuary and Bidasoa estuary. Reproductive cells, atresic reproductive cell, other cell type, ADG (Adipogranular connective tissue) cells and VCT (vesicular connective tissue) cells partial volume at each sampling time over 2 year periods

whereas no significant seasonal effect in salinity was observed along the Basque coast in each analyzed year (Kruskal-Wallis test; $p=0.996$ and $p=0.231$, respectively) (Fig. 4C). Salinity varied more in estuaries, especially in Bidasoa estuary, which displayed significantly different salinity compared to the other studied sites (Mann-Whitney $U$ test; $\mathrm{p}<0.05$ ). Similar to salinity and Chl- $a$, nitrogen and phosphorous presented higher variability in estuaries compared to coastal zones (Fig. 5A, B). Regarding TN cycle (Fig. 5A), significant spatial differences were found in both years (Kruskal-Wallis test; $p=0.016$ and $p=0.022$, respectively). Coastal sites presented significantly lower TN (Mann-Whitney $U$ test; $p<0.05$ ). Seasonal differences were not found for TN concentration in any of the studied years (Kruskal-Wallis test; $p=0.313$ and $p=0.371$, respectively). Regarding TP cycle, significant differences were found among sites in both years (Kruskal-Wallis test; $p=0.009$ and $p=0.007$, respectively). Coastal sites in open nearshore waters also presented significantly lower TP concentrations than estuarine sites (Mann-Whitney $U$ test; $p<0.05$ ). Maximum concentration was found in Nerbioi estuary, with almost $5 \mu \mathrm{M}$ (Fig. 5B). In Oiartzun and Bidasoa 
Nerbioi coast

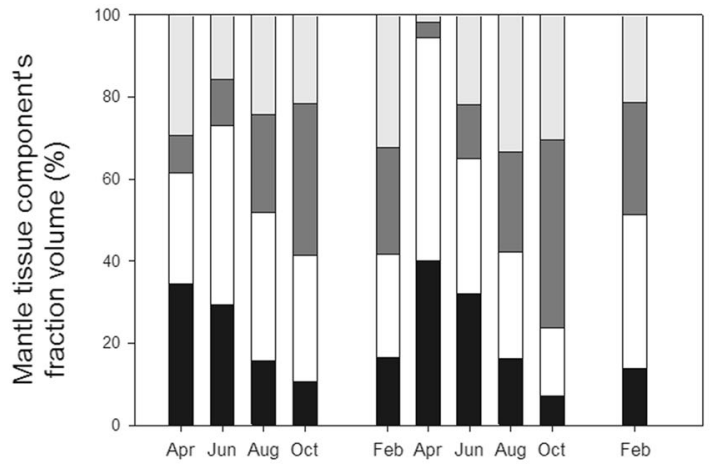

Mutriku coast

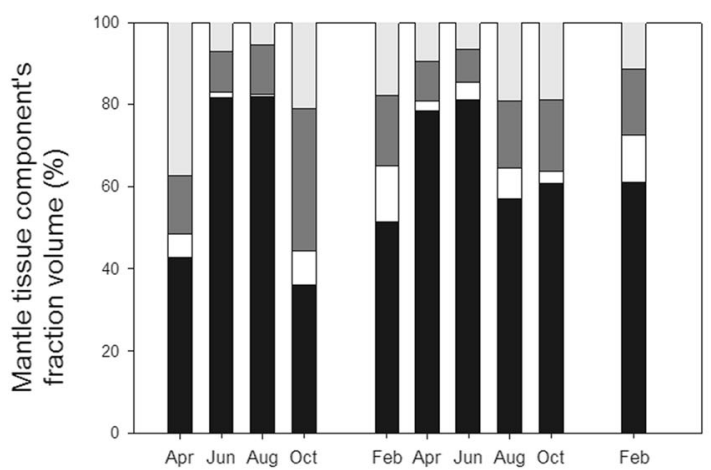

Bidasoa estuary

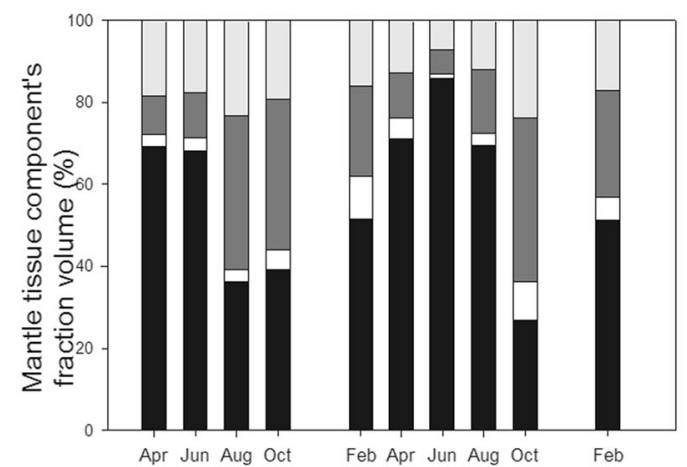

Nerbioi estuary

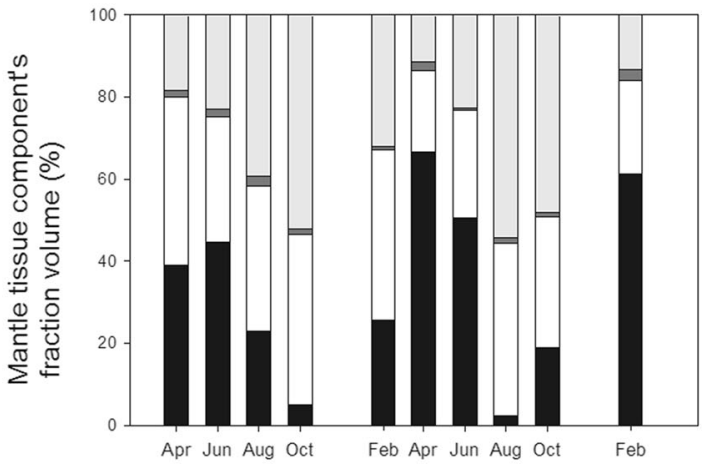

Oiartzun estuary

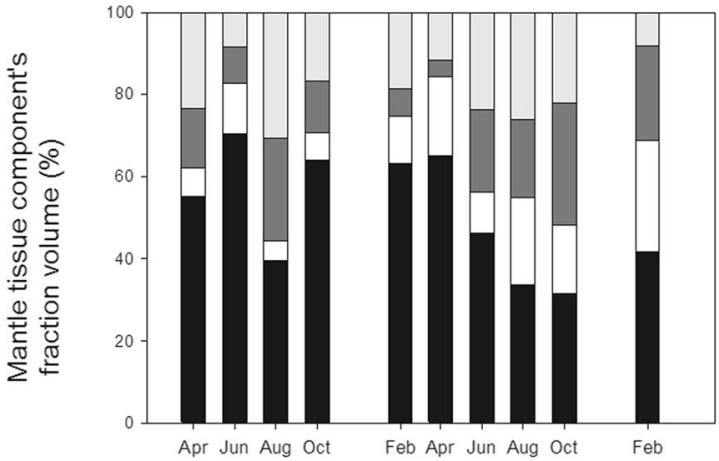

Fig. 10 Variation on male mussel mantle tissue components volume fraction (stacked bars) in the five studied sites. From top left to right: Nerbioi coast, Nerbioi estuary, Mutriku coast, Oiartzun estuary and Bidasoa estuary. Reproductive cells, other cell type, ADG (Adipogranular connective tissue) cells and VCT (vesicular connective tissue) cells partial volume at each sampling time over 2 year periods

estuaries TP peaks were between 2 and $3 \mu \mathrm{M}$. In the exposed coastal sites the highest TP concentration reached only $1 \mu \mathrm{M}$. No seasonal cycle in TP concentration was observed along the Basque coast, in either of the studied years (Kruskal-Wallis test; $p=0.852$ and $p=0.850$, respectively).

TOC ranged from 50 to $150 \mu \mathrm{M}$. A spatial pattern was not detected (Two-way ANOVA; $p=0.607$ ), even though TOC was significantly different within sites each year (Two-Way ANOVA; $p=0.028$ ) (Fig. 5C). Significantly higher TOC was observed during the second year $(t$ test; $p=0.020)$. No significant interaction was observed between sites for each year (Two-way ANOVA; $p=0.964$ ). Regarding seasonality of TOC along the Basque coast, TOC presented a seasonal pattern only in the second year (Kruskal-Wallis test; $p=0.003$ ). SS along the Basque coast did not vary seasonally in either of the studied years (Kruskal-Wallis test; $p=0.060$ and $p=0.181$, respectively). Values ranged from 0 to $50 \mathrm{mg} \mathrm{l}^{-1}$ (Fig. 5D). Regarding sites, 
no spatial differences were detected in either of the studied years (Kruskal-Wallis test; $p=0.121$ and $p=0.051$, respectively).

Spatial visualization of relationships among environmental variables

The results of PCA are shown in Fig. 6. The analysis was performed with environmental data on total nitrogen (TN), total phosphorous (TP), suspended solids (SS), temperature, as well as salinity acquired during both studied years. A large proportion of the variability (69\%) was explained by two components. The first component was closely associated with TP (association coefficient: 0.864 ), TN (association coefficient: 0.847) and also with salinity (association coefficient: -0.586 ) and served to separate sampled coastal sites from sampled estuarine sites. The second component showed a close association among both temperature (association coefficient: 0.919) and suspended solids (SS) (association coefficient: - 0.750) and a looser association with salinity (association coefficient: 0.305 ) and served to separate sampled seasons.

Sex ratio

Statistically significant bias in the sex ratio of the whole studied population (Chi-sq $=0.793, p=0.373$ ) was detected in comparison with the theoretical sex-ratio in mussel populations (1:1), with a female:male sex ratio (0.94F:1M, $n=919)$ for the total of both years. Among sites, a statistically significant bias of more males was observed in Mutriku coast (Chi-sq $=7.321, p=0.007$ ). On the other hand, from the total of 1000 individuals observed and assessed for their gametogenic stage, only two hermaphrodite animals $(0.2 \%)$ were found, both in Oiartzun estuary. These hermaphrodite individuals showed separate male and female follicles in their mantle tissue (see Fig. 2M, N). Finally, an undifferentiated stage of development, where no gametes were present, was observed in $8 \%$ of analyzed individuals.

Gamete development and gonad index

The gonad index analysis showed the effective presence of all stages.

\section{Resting/spent gonad}

Stage 0 Inactive or undifferentiated (Figs. 2A, 3A, 3K). This stage is characterized by rapid regeneration of the reserve tissue and by an absence of follicles

\section{Developing gonad}

Stage 1 Gametogenesis has begun; no ripe gametes visible (Figs. 2B, C, 3B); stage 2: Ripe gametes present; gonad developed to about one-third of its final size (Figs. 2D, 3C); stage 3: Gonad increased in mass to about half the fully ripe condition; each follicle contains, in area, about equal proportions of ripe and developing gametes (Figs. 2E, 3D); stage 4: Gametogenesis still progressing, follicles contain mainly ripe gametes (Figs. 2F, 3E). During the development of the gonad reserve tissue abounds and as the volume of follicles increases the reserve tissue decreases

\section{Ripe gonad}

Stage 5 Gonad fully ripe, early stages of gametogenesis rare; follicles distended with ripe gametes; ova compacted into polygonal configurations (Fig. 2G) and sperm with visible tails (Fig. 3F). The reserve tissue is completely exhausted 


\section{Spawning gonad}

Stage 4 Active emission has begun; ova rounded off as pressure within follicles is reduced (Figs. 2H, 3G, H); stage 3: Gonad about half empty (Figs. 2I, 3I); stage 2: Gonadal area reduced; follicles about one-third full of ripe gametes (Figs. 2J, 3J)

In winter, spawning is not very intense and both spawning and restorations of the gonad are slow processes. In winter reserve tissue is abundant and a high atresia with a degradation of gametes can be observed. In spring, spawning is intense and both spawning and restorations are rapid processes. Spawning in both sexes is massive and synchronous which leaves mantle tissue practically empty of follicles and the reserve tissue fully consumed.

Nevertheless, mussel populations along the Basque coast showed a marked seasonal cycle of gamete development in both studied years (Kruskal-Wallis test; $p<0.001$ ) (Fig. 7). These results were also well illustrated by box plots (medians were particularly differentiated) (Fig. 8). Results are presented in terms of two reproductive years (year 1: April 2010-Feb 2011; and year 2: April 2011-Feb 2012).

Along the Basque coast in the first studied year gametogenesis onset was observed from spring (2010) to early summer (2010). Subsequently, from early summer (2010) to late summer (2010) spawning stage was observed, with the end of the gametogenic cycle observed in late summer (2010). New gametogenesis was observed from fall (2010) to winter (2011). In the second year, gametogenesis proceeded in spring (2011) and spawning stage was observed from spring (2011) and continued until fall (2011), indicating a larger spawning period during this second summer. Consequently, in this second year the end of gametogenic cycle was observed later, in fall (2011). Gametogenesis onset was observed in winter (2012).

Microscopic observation of gonads from the 2 years showed differences in gamete development patterns among sites (Kruskal-Wallis test; $p<0.001$ ). GI seasonal cycle clearly separated open coastal sites from western estuarine sites (Mann-Whitney $U$ test; $p<0.05$ ), but the seasonal cycle observed in Nerbioi coast and estuary did not differ significantly (Mann-Whitney $U$ test; $p=0.454$ ). Regarding differences among estuaries, significant differences were also observed in the seasonal cycle between western estuarine site (Nerbioi estuary) and eastern estuarine sites (Oiartzun and Bidasoa estuary) (Mann-Whitney $U$ test; $p<0.001$ and $p<0.001$, respectively).

At each analyzed site, in the two observation years the seasonal cycles of gamete development and GI showed significant differences between genders (Wilcoxon Signed Ranks test; $p<0.05$ ). However, in Bidasoa estuary during the first studied year as well as in Nerbioi coast during the second studied year genders showed similar mean seasonal GI (Wilcoxon Signed Ranks test; $p=0.080$ and $p=0.345$, respectively).

\section{Stereology}

The relative proportion of mantle/gonad tissue cellular components is shown in Figs. 9 and 10, for female and male mussels, respectively.

The mantle/gonad tissue cellular component proportions (i.e., proportions of reproductive cells and reserve tissue: ADG and VCT cells) observed in both genders in the two studied years along the Basque coast showed a marked seasonal cycle (Kruskal-Wallis test; $p<0.001$ ), whereas the proportion of haemocytes in gonads did not show any seasonality in either of the two studied years (Kruskal-Wallis test; $p=0.780$ and $p=0.885$ ). The level of oocyte atresia showed a seasonal cycle in the first studied year (Kruskal-Wallis test; $p=0.029$ ) but not the following year (Kruskal-Wallis test; $p=0.963$ ).

With respect to reproductive cells along the Basque coast in the first year, highest proportions were observed in early summer (2010) and thereafter proportions decreased to minimum levels in late summer (2010), whereas in the second year, highest proportion of reproductive cells were observed in spring (2011) and thereafter decreased to minimum levels in fall (2011).

Regarding reserve tissue, the proportion of ADG cells in the first year increased from early summer (2010) to late summer (2010). From late summer (2010) to winter (2011) the level of ADG decreased slightly but remained high. In the second year, the proportion of ADG cells increased from minimum levels observed in spring (2011) to maximum levels observed in fall (2011). From fall (2011) to winter (2012) the level of ADG decreased but remained high. Regarding VCT cells, in the first year lowest proportions were observed in early 
summer (2010). Over summer the proportion of VCT cells increased to maximum levels, whereas from late summer (2010) to winter (2011), levels decreased slightly but remained high. In the following year, low proportions were observed in spring (2011). From spring (2011) to fall (2011) an increase in the proportion of VCT cells was observed, whereas from fall (2011) to winter (2012) the proportion of VCT cells decreased.

Concerning haemocytes, no seasonal cycle was observed but highest proportions of haemocytes were observed in fall in the two studied years.

The seasonal cycle of gonad tissue cellular components (i.e., reproductive cells, reserve tissue cells and haemocytes) were significantly different among studied sites in both studied years (Kruskal-Wallis test; $p<0.001)$. Significant differences in the proportion of reproductive cells as well as in the proportion of ADG and VCT cells were observed between Oiartzun estuary and the other studied sites (Mann-Whitney $U$ test; $p<0.001)$. In addition, regarding reserve tissue cells, on one hand, significant difference in the proportion of ADG cells was observed between the two studied coastal sites, Nerbioi coast and Mutriku coast (MannWhitney $U$ test; $p=0.011$ ). On the other hand, regarding VCT cells proportion, Bidasoa estuary, as observed with the other eastern estuary (Oiartzun estuary), showed significantly different VCT cells cycle compared to the other studied sites (Mann-Whitney $U$ test; $p<0.05$ ).

Regarding haemocytes, significant differences were observed among mussels (both genders) from all studied sites (Mann-Whitney $U$ test; $p<0.05$ ), with the exception of Nerbioi coast and estuary (MannWhitney $U$ test; $p=0.737)$.

Regarding differences among genders at each studied site, over both studied years, significant were observed (Wilcoxon Signed Ranks test; $p<0.05$ ). Nevertheless, when each of the two studied years was analyzed separately, Nerbioi estuary showed no difference between genders (Wilcoxon Signed Ranks test; $p=0.345$ and $p=0.080$ ). Regarding the seasonal cycle of reserve tissue cells (ADG and VCT cells), no significant differences were observed between genders at each studied site (Wilcoxon Signed Ranks test; $p>0.05)$. To the contrary, regarding the seasonal cycle of haemocytes, significant differences between genders were observed in all studied sites (Wilcoxon Signed Ranks test; $p>0.05$ ).

Finally, the proportion of atresic oocytes observed in all sites and all samplings in each of the two studied years was below 20\%. Along the Basque coast no difference in the proportion of oocyte atresia among studied sites were observed in both years (Kruskal-Wallis test; $p=0.0 .057$ and $p=0.780$, respectively).

\section{Discussion}

Influence of environmental conditions on the reproductive cycle

The timing and duration of the reproductive cycle of aquatic organisms, such as Mytilus galloprovincialis Lmk., in temperate regions, varies seasonally due to local environmental conditions, especially temperature and food availability (Seed 1976; Bayne 1976; Sastry 1979; Sunila 1981; Kautsky 1982; Lowe et al. 1982; Newell et al. 1982; Sprung 1983; Rodhouse et al. 1984; Villalba 1995; Múgica et al. 2015). On the Basque continental shelf, as in other temperate areas located at mid-latitude, the annual cycle of the sea surface temperature (SST) shows a marked seasonality related strongly to atmospheric temperatures. There are two clearly defined seasons, winter and summer; and two transitional seasons, spring and fall. The SST differentiates the period of vertical mixing from the stratification period (Valencia et al. 2004; Fontán et al. 2008). This typical seasonal cycle in the SST was also found during this study.

Regarding food availability for successful reproduction, females and males require enough energy to carry out reproductive processes and indeed, the percentage of individuals at each gametogenic stage is related to food availability in the surrounding environment (Sastry 1979; Bayne and Newell 1983; Avellanal et al. 2002). When phytoplankton availability decreases, mussels can use their own reserves (Bayne 1976) or alternative food sources, such as dissolved organic matter, bacteria and organic aggregates (Sastry 1979).

In the studied area, although statistical differences were not significant, Chl- $a$ peaked in the estuaries during spring and summer, while lower peaks were found in fall and winter at the open coastal sites. Similar spatial patterns and seasonal cycles have been observed in previous studies of phytoplankton biomass dynamics along the Basque coast (Revilla et al. 2009; Garmendia et al. 2011). In the present study, the number of sampling 
campaigns conducted for Chl- $a$, which varies greatly at different temporal scales in coastal waters, probably was insufficient to achieve a higher statistical significance.

The highest peaks of Chl- $a$ in the Basque estuaries are usually found in summer, when water residence time increases and insolation is higher (Orive et al. 2004; Garmendia et al. 2011). Similarly, regarding alternative energy sources (in special, organic carbon) on average the estuarine waters were richer than the exposed coastal sites. A consistent seasonal pattern was not found for total organic carbon and suspended solids concentration. However, it was higher during winter and/or fall. This reflects the riverine origin of other energy sources than phytoplankton at the studied estuarine sites, as freshwater discharges in the southern Bay of Biscay are higher during the cold seasons (Prego and Vergara 1998; Prego et al. 2007).

Regarding salinity, both Mutriku and Nerbioi nearshore waters showed almost constant conditions, similar to the open sea, and thus, no metabolic stress would be expected there due to salinity. Salinity varied little in the Oiartzun and Nerbioi estuarine sites, in euhaline conditions. In the Bidasoa estuary, however, salinity was lower and more variable (polyhaline conditions). The salinity at Bidasoa estuary could influence the desired reproductive performance of wild mussel populations. In this sense, Jansen et al. (2007) indicated that, in the Bay of Biscay, temporary drops in salinity could induce metabolic depression in Mytilus species.

PCA results showed the overall seasonal and spatial trends of environmental variables at the five studied sites along the Basque coast. The nearshore open coastal waters and the estuarine sites were clearly differentiated due to salinity and alternative food sources in water, whereas temperature cycle and suspended solid patterns served to describe the variability observed among sampled seasons.

Spatial and temporal variability in the reproductive cycle

Wide differences are found in the pattern of Mytilus galloprovincialis Lmk. gonad development of different geographical areas (Seed 1976; Da Ros et al. 1985). Indeed, the gonad index values obtained in this study indicate that all stages can be found within the population at any season. However, differences between mussels located at nearby sites have also been reported, and are explained by environmental variables such as differences in food availability (Newell et al. 1982; Rodhouse et al. 1984; Ferrán 1992). The environmental variables divided clearly summer and winter seasons and characterize those seasons as different in studied estuarine and coastal sites (Fig. 6).

This study showed the same reproductive pattern as mussels from previous studies in the SE Bay of Biscay (Ortiz-Zarragoitia et al. 2011; Ortiz-Zarragoitia and Cajaraville 2010; Garmendia et al. 2010; Cuevas et al. 2015). Using stereological data from the present study, it can be concluded that animals undergo gametogenesis during winter months, deriving energy from stored reserves, as described by Pipe (1987).

In this study, levels of VCT cells were higher in spring and in fall (Figs. 9, 10). However, VCT cell levels were relatively high in all studied populations in both studied years. The eastern studied sites, Oiartzun and Bidasoa estuaries, showed high VCT cell levels from spring to fall. This may well have been related to the high food availability (Chlorophyll- $a$ and TN) in that season in those estuaries (Figs. 4B, 7A). On both studied coastal sites, Nerbioi and Mutriku coasts, VCT cell levels rose from late summer to winter, in concordance with the high food availability [Chlorophyll- $a$ concentration (Fig. 4B) and TOC (Fig. 5C)] at these coastal sites. By contrast, the western studied estuary, Nerbioi estuary, showed higher levels of VCT cells from late summer to winter in the first year, while in the following year, high levels of VCT cells were observed from late summer (2011) to fall (2011). Nevertheless, non-phytoplanktonic food sources [TOC level (Fig. 5C) or other sources such as SS (Fig. 5D)] seem to be related to this seasonal reserve tissue production at Nerbioi estuary, as in the present study, estuaries showed higher food sources (Chl-a) during spring and summer seasons (Fig. 4B). No differences in reserve tissue, both ADG and VCT cells, cycles were detected between genders at each sampled site (Figs. 9, 10).

In this study, mussel populations showed one spawning period in 2010 and another one in 2011, both of which typically started in spring and ended in late summer (Fig. 7). Over the 2-year period, however, in certain sites, the spawning period ended in early summer. For instance, in both the Mutriku coast and Oiartzun estuary in the first studied year (2010), and in both the Nerbioi coast and estuary in the following year (2011), the spawning period was reduced from spring to early summer or just to early summer. In Mutriku coast and Oiartzun estuary the reduced spawning period is likely to be caused by low food availability observed in both coastal and estuarine sites in late summer (2010) in the first studied year, compared to the following late 
summer (2011) (Fig. 4C). In both Nerbioi coast and estuary, high riverine input from Nerbioi river maintains a high concentration of Chlorophyll- $a$ in summer (Fig. 4C). The input in 2010 may not have been enough for the active reproductive period to continue until the end of summer.

In contrast to the reduced spawning period described above, in other sites two reproductive cycles were observed. For instance, in the Bidasoa estuary in the first studied year (2010), two spawning periods were observed (from spring to late summer, and another in the fall), while in the following year (2011), only one was observed (Fig. 7). This year-to-year variability among abiotic factors create variability in the gonad cycle of individuals of the same site (Seed 1976; Ferrán 1992) and as a result fall spawning may occur some years (Andreu 1958; Aguirre 1979; Villalba 1995). A second spawning peak has been described previously in the fall in mussels from the Basque coast (Garmendia et al. 2010; Múgica et al. 2015). The second spawning period observed in Bidasoa estuary during the fall of 2010, may also be related to the high presence of spawning individuals analyzed throughout both studied years (Fig. 7). Furthermore, this continuous spawning of individuals may be induced in summer by temperatures above thermal stress (Múgica et al. 2015), and/or by temporal drops in salinity occurring at any time throughout the year (Fig. 4A, C).

No significant female:male sex-ratio bias was measured on Nerbioi coast, nor in Nerbioi, Oiartzun and Bidasoa estuaries, and the resulting ratio was close to that of 1:1, consistent with findings of Ortiz-Zarragoitia et al. (2011) in the SE Bay of Biscay. By contrast, significant sex-ratio bias in favor of males was measured on Mutriku coast. In some natural bivalve populations there is a higher percentage of females than males (Mackie 1984; Toro et al. 2002). The degree of bias is a characteristic property of the female parent, as mating of the same female with different males produces the same sex-ratio, but mating of the same male with different females produces different sex ratios (Kenchington et al. 2002).

Both sexes were found to display relative similarities in the timing of reproductive cycles. By contrast, on the Mutriku coast and in the Oiartzun estuary there was not such a synchrony between sexes (Figs. 9, 10). On the Mutriku coast, in addition to the sex-ratio bias in favor of males, male mussels also showed differences to female mussels in the timing of reproductive cycles, and hence, spawning. Despite these differences in the timing of spawning, relative common spawning periods between both genders were observed on the Mutriku coast (i.e., early summer in the first studied year and from spring to late summer in the following year). In the Oiartzun estuary, synchronized spawning periods between both genders were also observed (i.e., from spring to early summer in the first studied year, and in spring in the following year). Furthermore, it was at this particular site that the only two hermaphroditic individuals of the study were found (Fig. 2M, N). Despite these apparent limitations, the populations' physiology was healthy and in Oiartzun estuary environmental conditions were observed to be favorable in the fall and winter in the first studied year (2010). In addition, the low hermaphroditic level found at this site is in concordance with previous data reported by Sunila (1981) for M. edulis; by Lubet (1959) for M. edulis and M. galloprovincialis in different geographical areas; and by Ortiz Zarragoitia et al. (2011) and by Cuevas et al. (2015), in the SE Bay of Biscay for M. galloprovincialis Lmk. specie.

When mature female gametes are not effectively spawned, these gametes are broken down at gonoduct level without being released (Suárez Alonso et al. 2010). This occurrence, oocyte atresia (Fig. 2K), is caused by unfavorable conditions such as low temperatures or low food availability, which ultimately prevent mature female mussels from spawning (Sastry 1979; Suárez Alonso et al. 2010). Similarly, Suárez Alonso et al. (2010) found that in late summers, with high temperatures and less proportion of gonads occupied by gametes, a rise in atresic oocytes in mussels was produced, indicating the end of the gametogenic cycle. An increase in the normal levels of oocyte atresia have also been attributed to pollutants (Puy-Azurmendi et al. 2010) or thermal stress (Múgica et al. 2015) of mussels inhabiting the Basque coast. Indeed, Ortiz-Zarragoitia et al. (2011) suggested that pollution-causal production of atresic oocytes increased in association with higher defense metabolism and further energy consumption. Hence, the trend on oocyte atresia increase observed in this study (Fig. 9), is most likely due to the end of gametogenic cycle. The atresia level was higher from late summer until winter, corresponding with the end of the spawning period and resting period, respectively. Whereas, minimum levels were found from spring to early summer, during active gametogenic period and spawning time. Moreover, the level of oocyte atresia in the studied populations along the Basque coast was normal compared to the level of oocyte atresia found in mussel from Urdaibai in 2003 by Ortiz-Zarragoitia and Cajaraville (2010). The high prevalence of oocyte atresia observed at those female mussels suggested that 
their reproduction ability could have been impaired. Therefore, oocyte atresia caused by pollution could not be confirmed in this study.

\section{Conclusions}

The present study provides a detailed description of the reproductive cycle of five mussel populations inhabiting the coast of the SE Bay of Biscay ( 2 in coastal exposed waters and 3 in estuarine sheltered waters). The reproductive cycle of the mussel populations inhabiting those sites was assessed using gonad index and stereology. Along the Basque coast gametogenesis onset was observed from winter to spring, with spawning occurring from spring till summer. This was followed by a resting phase and an increase in reserve tissues (ADG cell) in fall. Generally, mature mussels stayed ripe during winter until favorable environmental conditions were met in spring. Therefore, it can be suggested that to secure and protect potential maximum natural reproductive outputs, mussel harvesting should be avoided from spring to the end of summer, on the Basque coast. It was observed in the 2-year period of the study that the reproductive cycles of the studied populations did not follow a consistent pattern. Indeed, differences were found among sites, and year-to-year variability was observed at each site. In addition, at two of the studied sites asynchrony was observed between genders in the timing of spawning. Indeed, these observed variability on gonad index or even in the gonad tissue cellular components might have been caused by unusual environmental event such as harsh winter, rainfall or even by pollution. Hence, more data is needed to establish a baseline gonad development pattern in the area. Nevertheless, these timing differences did not prevent mussels at those sites from reproducing successfully. Hence, these sites have the potential to become main sources of wild mussel spat for future expected commercial mussel farming in the Basque Country. Among the studied sites, the high food availability found in the Bidasoa estuary is propitious for achieving long and healthy active reproductive periods in mussels. Nevertheless, the final suitability of those sites as main source of mussel spat should be further studied through environmental and pollution monitoring.

Acknowledgements The environmental data were obtained from the project "Program for the monitoring and assessment of the ecological status of transitional and coastal waters of the Basque Country" funded by URA, the Basque Water Agency. We wish to thank Gaizka Bidegain, Joxemari Emezabal, and AZTI staff for their capable assistance during the laboratory and field works. Eudriano Costa for his help with ImageJ. Beñat Zaldibar, Aileen Logan and Emma Ruizdelgado for critically reviewed the manuscript and offered suggestions. This work was partially supported by the Department of Agriculture, Fisheries and Aquaculture and by a Ph.D. grant from the Education, Universities and Research Department of the Basque Government. This institution also provided support for this research through the projects "IM11IZATEK and IM16SIMMA". This paper is Contribution Number 825 from AZTI-Tecnalia (Marine Research Division).

Open Access This article is distributed under the terms of the Creative Commons Attribution 4.0 International License (http:// creativecommons.org/licenses/by/4.0/), which permits unrestricted use, distribution, and reproduction in any medium, provided you give appropriate credit to the original author(s) and the source, provide a link to the Creative Commons license, and indicate if changes were made.

\section{References}

Aguirre MP (1979) Biología del mejillón (M. edulis) de cultivo de la Ría de Vigo. Boletin Instituto Español Oceanografía 5(3):107-160

Andreu B (1958) Sobre el cultivo del mejillón en Galicia: biología, crecimiento y producción. Investigación pesquera 32:44-47

Avellanal MH, Jaramilo E, Clasing E, Quijon P, Contreras H (2002) Reproductive cycle of the bivalves Ensis macha (Molina, 1782) (Solenidae), Tagelus dombeii (Lamarck, 1818) (Solecurtidae), and Mulinia edulis (King, 1831) (Mactridae) in southern Chile. The veliger 45(1):33-44

Azpeitia K, Ferrer L, Revilla M, Pagaldai J, Mendiola D (2016) Growth, biochemical profile, and fatty acid composition of mussel (Mytilus galloprovincialis Lmk.) cultured in the open ocean of the Bay of Biscay (northern Spain). Aquaculture 454:95-108

Barber BJ, Blake NJ (1991) Reproductive Physiology. In: Shumway SE (ed) Scallops: biology, ecology and aquaculture. Elsevier, New York, pp 377-428

Bayne BL (1976) Marine mussels: their ecology and physiology, vol 10. Cambridge University Press, Cambridge

Bayne BL, Newell RC (1983) Physiological energetics of marine molluscs. In: Wilburg KM, Saleuddin ASM (eds), The Mollusca, vol. 4. Academic Press, London, pp. 407-515 
Borja A, Franco J, Valencia V, Bald J, Muxika I, Belzunce MJ, Solaun O (2004) Implementation of the European water framework directive from the Basque Country (northern Spain): a methodological approach. Mar Pollut Bull 48:209-218

Borja A, Bald J, Franco J, Larreta J, Muxika I, Revilla M, Valencia V (2009) Using multiple ecosystem components, in assessing ecological status in Spanish (Basque Country) Atlantic marine waters. Mar Pollut Bull 59(1):54-64

Bridger CJ, Costa-Pierce BA (2003) Open ocean aquaculture: from research to commercial reality. The World Aquaculture Society, Baton Rouge

Cuevas N, Zorita I, Costa PM, Franco J, Larreta J (2015) Development of histopathological indices in the digestive gland and gonad of mussels: integration with contamination levels and effects of confounding factors. Aquat Toxicol 162:152-164

Da Ros L, Bressan M, Marin MG (1985) Reproductive cycle of the mussel (Mytilus galloprovincialis Lmk) in Venice lagoon (North Adriatic). Ital J Zool 52(3-4):223-229

Dias PJ, Dordor A, Tulett D, Piertney S, Davies IM, Snow M (2009) Survey of mussel (Mytilus) species at Scottish shellfish farms. Aquac Res 40(15):1715-1722

Domínguez L, Villalba A, Fuentes J (2010) Effects of photoperiod and the duration of conditioning on gametogenesis and spawning of the mussel Mytilus galloprovincialis (Lamarck). Aquac Res 41(11):807-818

Ellis MS, Barber RD, Hillman RE, Powell EN, Port Norris NJ (1998) Gonadal analysis. Sampling and analytical methods of the National Status and Trends Program Mussel Watch Project: 1993-1996 Update, 216

Ferrán E J (1992) Ciclo gonadal y tejido de reserva del mejillón de las rías de Galicia Mytilus galloprovincialis Lmk. Doctoral thesis, Universidad de Santiago de Compostela. pp. 229

Fontán A, Valencia V, Borja Á, Goikoetxea N (2008) Oceano-meteorological conditions and coupling in the southeastern Bay of Biscay, for the period 2001-2005: a comparison with the past two decades. J Mar Syst 72:167-177

Gabbott PA (1976) Energy metabolism. In: Bayne BL (ed) Marine mussels: their ecology and physiology. Cambridge University Press, Cambridge, pp 293-355

Gabbott PA, Bayne BL (1973) Biochemical effects of temperature and nutritive stress on Mytilus edulis L. J Marine Biol Assoc UK 53(02):269-286

Garmendia L, Soto M, Cajaraville MP, Marigómez I (2010) Seasonality in cell and tissue-level biomarkers in Mytilus galloprovincialis: relevance for long-term pollution monitoring. Aquatic Biol 9(3):203-219

Garmendia M, Revilla M, Bald J, Franco J, Laza-Martínez A, Orive E, Seoane S, Valencia V, Borja Á (2011) Phytoplankton communities and biomass size structure (fractionated chlorophyll "a"), along trophic gradients of the Basque coast (northern Spain). Biogeochemistry 106(2):243-263

Gosling E (1992) Systematics and geographic distribution of Mytilus. The Mussel Mytilus; ecology, physiology, genetic and culture. Dev in Aquac Fish Sci 25

Hayes MO (1975) Morphology of sand accumulation in 28 estuaries: an introduction to the symposium. In: Cronin LE (ed), Estuarine Research, vol. 2. Academic Press, New York, pp. 3-22

Hesley C (1997) Open ocean aquaculture: chartering the future of ocean farming. In: Proceedings of an international conference. UNIHI-Seagrant-CP-98-08, University of Hawaii Sea Grant College Program, Maui, 23-25, April 1997

Hillman RE (1984) Gonadal index and histopathology for the East and West coasts used in the National Status and Trends Mussel Watch Project. Sampl Anal Methods Natl Status Trends Prog Natl Benthic Surveill Mussel Watch Proj 1992:45-53

Hillman RE (1993) Gonadal index and histopathology for the east and west coasts used in the national status and trends mussel watch project. In: Sampling, analytical methods for the national status, trends program national benthic surveillance, mussel watch projects 1984-1992, vol. II: comprehensive descriptions of complementary measurements. NOAA Tech. Mem. NOS ORCA 71. NOAA/NOS/ORCA, Silver Spring, MD, pp. 45-53

Izagirre U, Garmendia L, Soto M, Etxebarria N, Marigómez I (2014) Health status assessment through an integrative biomarker approach in mussels of different ages with a different history of exposure to the Prestige oil spill. Sci Total Environ 493:65-78

Jansen JM, Pronker AE, Kube S, Sokolowski A, Sola JC, Marquiegui MA, Hummel H (2007) Geographic and seasonal patterns and limits on the adaptive response to temperature of European Mytilus spp. and Macoma balthica populations. Oecologia 154(1):23-34

Kautsky N (1982) Growth and size structure in a Baltic Mytilus edulis population. Mar Biol 68(2):117-133

Kenchington E, MacDonald B, Cao L, Tsagkarakis D, Zouros E (2002) Genetics of mother-dependent sex ratio in blue mussels (Mytilus spp.) and implications for double uniparental inheritance of mitochondrial DNA. Genetics 161(4):1579-1588

Kim Y, Ashton-Alcox KA, Powell EN (2006) Gonadal analysis NOAA histological techniques for marine bivalve mollusks: up date NOAA technical memories NOS NCCOS 27. Spring, Berlin, pp 1-18

Langan R, Horton F (2003) Design, operation and economics of submerged longline mussel culture in the open ocean. Bull Aquac Assoc Canada 103:11-20

Lowe DM, Moore MN, Bayne BL (1982) Aspects of gametogenesis in the marine mussel Mytilus edulis L. J Marine Biol Assoc UK 62(01):133-145

Lubet P (1959) Recherches sur le cycle sexuel et l'emission des gamètes chez les mytilidés et les pectinidés (mollusques bivalves). Rev Trav Inst pêches Marit 23:387-542

Mackie GL (1984) Bivalves. Mollusca 7:351-418

Múgica M, Sokolova IM, Izagirre U, Marigómez I (2015) Season-dependent effects of elevated temperature on stress biomarkers, energy metabolism and gamete development in mussels. Marine Environ Res 103:1-10

Newell RI, Hilbish TJ, Koehn RK, Newell CJ (1982) Temporal variation in the reproductive cycle of Mytilus edulis L. (Bivalvia, Mytilidae) from localities on the east coast of the United States. The Biological Bulletin 162(3):299-310

Orive E, Franco J, Madariaga I, Revilla M (2004) Bacterioplankton and phytoplankton communities. In: Borja A, Collins M (eds) Oceanography and marine environment of the Basque Country, vol 70. Elsevier oceanography series. Elsevier, Amsterdam, pp 367-393 
Ortiz-Zarragoitia M, Cajaraville MP (2010) Intersex and oocyte atresia in a mussel population from the biosphere's reserve of Urdaibay (Bay of Biscay). Ecotoxicol environmental safety 73(5):693-701

Ortiz-Zarragoitia M, Garmendia L, Barbero MC, Serrano T, Marigómez I, Cajaraville MP (2011) Effects of the fuel oil spilled by the Prestige tanker on reproduction parameters of wild mussel populations. J Environ Monit 13(1):84-94

Pipe RK (1987) Ultrastructural and cytochemical study on interactions between nutrient storage cells and gametogenesis in the mussel Mytilus edulis. Mar Biol 96(4):519-528

Polk M (1996) Open ocean aquaculture. Proceedings of an international conference, May 8-10, 1996, Portland, Maine. Polk M (ed) New Hampshire = Maine Sea Grant College Program No. UNHMP-CP-SG-96-9. Pp. 640

Prego R, Vergara J (1998) Nutrient fluxes to the Bay of Biscay from the Cantabrian rivers (Spain). Oceanol Acta 21:271-278

Prego R, Boi P, Cobelo-García A (2007) The contribution of total suspended solids to the Bay of Biscay by Cantabrian Rivers (northern coast of the Iberian Peninsula). J Mar Syst 72(1):342-349

Puy-Azurmendi E, Ortiz-Zarragoitia M, Kuster M, Martínez E, Guillamón M, Domínguez C, Serrano T, Carmen M, López M, Alda D, Bayona JM, Barceló D, Cajaraville MP, Barbero MC, Lopez de Alda M (2010) An integrated study of endocrine disruptors in sediments and reproduction-related parameters in bivalve molluscs from the Biosphere's Reserve of Urdaibai (Bay of Biscay). Marine Environ Res 69:S63-S66

Rasband WS (2009) 1997-2011. ImageJ. National Institutes of Health, Bethesda

Revilla M, Franco J, Bald J, Borja Á, Laza A, Seoane S, Valencia V (2009) Assessment of the phytoplankton ecological status in the Basque coast (northern Spain) according to the European Water Framework Directive. J Sea Res 61:60-67

Rodhouse PG, Roden CM, Burnell GM, Hensey MP, McMahon T, Ottway B, Ryan TH (1984) Food resource, gametogenesis and growth of Mytilus edulis on the shore and in suspended culture: killary harbour, Ireland. J Marine Biol Assoc UK 64(03):513-529

Sastry AN (1979) Pelecypoda (excluding ostreidae). Reprod Marine Invertebr 5(5):113-292

Seed R (1975) Reproduction in Mytilus (Mollusca: Bivalvia) in European waters. Pubblicazioni della Stazione Zoologica di Napoli (Milan) 39(Suppl.1):317-334

Seed R (1976) Ecology. In: Bayne BL (ed) Marine mussels: their ecology and physiology, IBP 10. Cambridge University Press, Cambridge, pp 13-65

Sprung M (1983) Reproduction and fecundity of the mussel Mytilus edulis at Helgoland (North Sea). Helgol Meeresunters 36(3):243-255

Stickney RR (1998) Joining forces with industry-open ocean aquaculture. In: Proceedings of the third annual international conference. TAMU-SG-99-103, Corpus Christi, Texas Sea Grant College Program. pp. 10-15

Suárez Alonso P, Álvarez González C, Molist García P, San Juan Serrano F (2010) Atresia gonadal durante el ciclo gametogénico de Mytilus galloprovincialis Lamarck, 1819 cultivado en la ría de Vigo (noroeste de la península Ibérica). Boletín Instituto Español de Oceanografía 23(1-4):3-10

Sunila I (1981) Reproduction of Mytilus edulis L.(Bivalvia) in a brackish water area, the Gulf of Finland. In: Annales Zoologici Fennici. Finnish Academy of Sciences, Societas Scientiarum Fennica, Societas pro Fauna et Flora Fennica and Societas Biologica Fennica Vanamo. pp. 121-128

Thompson RJ (1984) Production, reproductive effort, reproductive value and reproductive cost in a population of the blue mussel Mytilus edulis from a subarctic environment. Mar Ecol Prog Ser 16(3):249-257

Toro JE, Thompson RJ, Innes DJ (2002) Reproductive isolation and reproductive output in two sympatric mussel species (Mytilus edulis, M. trossulus) and their hybrids from Newfoundland. Mar Biol 141(5):897-909

Valencia V, Franco J, Borja Á, Fontán A (2004) Hydrography of the southeastern Bay of Biscay. In: Borja Á, Collins M (eds) Oceanography and marine environment of the Basque country, vol 70. Elsevier oceanography series. Elsevier, Amsterdam, pp 160-194

Villalba A (1995) Gametogenic cycle of cultured mussel, Mytilus galloprovincialis, in the bays of Galicia (NW Spain). Aquaculture 130(2):269-277

Weibel ER, Elias H (1967) Introduction to stereologic principles. Quantitative methods in morphology/quantitative methoden in der morphologie. Springer, Berlin, pp 89-98

Weibel ER, Kistler GS, Scherle WF (1966) Practical stereological methods for morphometric cytology. J Cell Biol 30(1):23

\section{Publisher's Note}

Springer Nature remains neutral with regard to jurisdictional claims in published maps and institutional affiliations. 